\title{
Clinical implications of p53 tumor suppressor gene mutation and protein expression in esophageal adenocarcinomas: Results of a ten-year prospective study
}

\author{
Alan G. Casson, FRCSC, ${ }^{\text {ab }}$ Susan C. Evans, BSc, ${ }^{\text {b }}$ Amy Gillis, BSc, ${ }^{\text {b }}$ Geoffrey A. Porter, MD, ${ }^{\text {ac }}$ Paul Veugelers, PhD, ${ }^{c}$ \\ S. Jane Darnton, $\mathrm{PhD}^{\mathrm{b}}$ Duane L. Guernsey, $\mathrm{PhD},{ }^{\mathrm{b}}$ and Pierre Hainaut, $\mathrm{PhD}^{\mathrm{d}}$
}

From the Departments of Surgery, ${ }^{\mathrm{a}} \mathrm{Pa}-$ thology, ${ }^{\mathrm{b}}$ and Community Health and Epidemiology, ${ }^{\mathrm{c}}$ Dalhousie University, Halifax, Nova Scotia, Canada, and the Molecular Carcinogenesis Group, International Agency for Research on Cancer, ${ }^{\mathrm{d}}$ Lyon, France.

Funded by The Dalhousie Medical Research Foundation, The Dalhousie University Department of Surgery, The Cancer Care Nova Scotia Surgical Oncology Network, and The QEII Health Science Centre Research Fund. Amy Gillis was supported by a Canadian Institutes for Health Research-Burrows Wellcome Fund/University of Toronto Faculty of Medicine Student Research Award (2001).

Read at the Eighty-second Annual Meeting of The American Association for Thoracic Surgery, Washington, DC, May 5-8, 2002.

Received for publication May 14, 2002. accepted for publication Aug 5, 2002.

Address for reprints: Alan G. Casson, MD, Division of Thoracic Surgery, QEII Health Sciences Centre, Victoria Building 7S-013, 1278 Tower Rd, Halifax, Nova Scotia, B3H 2Y9, Canada (E-mail: alan.casson@dal.ca).

J Thorac Cardiovasc Surg 2003;125: 1121-31

Copyright () 2003 by The American Association for Thoracic Surgery

0022-5223/2003 $\$ 30.00+0$

doi:10.1067/mtc.2003.176
Objective: This study was undertaken to characterize the spectrum of p53 alterations (mutations and protein expression) in surgically resected esophageal adenocarcinomas, and to correlate molecular alterations with clinicopathologic findings and outcome.

Methods: Between 1991 and 2001, 91 consecutive patients with esophageal adenocarcinomas underwent subtotal esophagectomy. No patient received induction therapy. Strict clinicopathologic criteria were used to define primary esophageal adenocarcinomas. Genomic DNA was extracted from esophageal tumors, each matched with histologically normal esophageal epithelium (internal control) from the resection margin. Polymerase chain reaction was used to amplify p53 exons 4 through 10. Mutations were studied by single-strand conformation polymorphism analysis and direct DNA sequencing. Immunohistochemical testing (monoclonal antibody DO7) was used to evaluate p53 protein distribution.

Results: Five-year overall survival was $27.3 \%$. No p53 alterations (mutations and/or protein overexpression) were found in normal esophageal epithelium. A total of $57.1 \%(\mathrm{n}=52)$ of tumors had p53 alterations (mutations and/or protein overexpression), which on univariate analysis were associated with poor tumor differentiation $(P=.001)$, advanced pTNM stage $(P=.009)$, and number of involved lymph nodes $(0,1-3,>3 ; P=.04)$. Patients with p53 alterations had significantly reduced 5-year overall survival relative to patients with wild-type p53 (15\% vs 46\%; $P=.004)$. The p53 mutations were predominantly $\mathrm{G}: \mathrm{C}$ to A:T transitions at $\mathrm{CpG}$ dinucleotides $(52.2 \%, 24 / 46)$

Conclusions: We conclude that p53 alterations (mutations and/or protein overexpression) are a predictor of reduced postoperative survival after surgical resection of esophageal adenocarcinomas and that p53 may be a clinically useful molecular marker for stratifying patients in future clinical trials. Patterns of p53 mutations suggest endogenous mutational mechanisms.

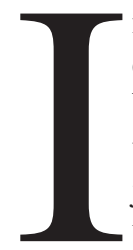

$\mathrm{n}$ North America and Europe there has been a marked change in the epidemiologic patterns of esophageal cancer during the past 3 decades. ${ }^{1,2}$ Whereas the incidence of squamous cell carcinoma has remained steady, the incidence of adenocarcinomas of the esophagus and esophagogastric junction has increased rapidly. The reasons for this change are largely unknown and remain controversial. Epidemiologic studies ${ }^{3-6}$ have implicated several lifestyle risk factors, including tobacco exposure, alcohol consumption, diet, obesity, and gastroesophageal reflux for esophageal adenocarcinoma. Recent molecular studies have also reported genetic alterations of various oncogenes and tumor suppressor genes in esophageal tumors (for recent reviews see references 7-10).

Tumor suppressor genes play important roles in the regulation of cell growth, 


\section{TABLE 1. Clinicopathologic criteria to define adenocarci- nomas of primary esophageal origin}

1. Barrett epithelium

2. $>75 \%$ tumor mass involving the tubular esophagus

3. Direct invasion of periesophageal tissues

4. Minimal gastric involvement

5. Clinical symptoms of esophageal obstruction (eg, dysphagia)

Criteria may be evaluated radiologically, endoscopically, at surgery or pathologically. ${ }^{13,33}$ For patients in whom Barrett epithelium (intestinal metaplasia defined histologically) cannot be demonstrated, criteria 2 through 5 must be established.

differentiation, and DNA repair. The p53 tumor suppressor gene appears to have a key role in human carcinogenesis, ${ }^{11}$ and p53 mutations are among the most frequent in human cancers. ${ }^{12}$ With strict clinicopathologic criteria used to define adenocarcinomas of primary esophageal origin, we reported p53 mutations in primary esophageal adenocarcinomas ${ }^{13}$ and associated premalignant Barrett epithelium in 1991. ${ }^{14}$ These original observations have now been confirmed by several investigators, documenting additional p53 mutations and changes in protein expression. ${ }^{15-20}$ However, the clinical significance and potential applications of these observations remain unclear. ${ }^{21-32}$

In February 1991, representing the first appointment of the senior author (A. G. C.), a prospective study was initiated to characterize the spectrum of p53 alterations in surgically resected primary esophageal adenocarcinomas. After a detailed molecular analysis of tumors banked during the first 5 years, we reported significant associations between p53 alterations (mutations and/or protein overexpression) and tumor differentiation, lifestyle risk factors, and survival. ${ }^{33}$ The objective of this report is to update the results of the second 5-year interval (up to February 2001) of this 10-year study, to document the spectrum of p53 mutations in primary esophageal adenocarcinomas, and to further evaluate associations between p53 and clinicopathologic findings and outcome.

\section{Patients and Methods \\ Patients}

This updated 10-year series comprised 91 sequentially accrued patients ( 73 male and 18 female) treated by a single surgeon (A.G.C.) between February 1991 and February 2001. All patients had a histologic diagnosis of adenocarcinoma made from biopsy samples obtained at esophagogastroscopy. Preoperative staging consisted of computed tomography of the chest and upper abdomen. Endoscopic ultrasound and positron-emission tomography were not available for staging. All patients were considered to have locally resectable tumors, with no clinical evidence of distant visceral metastases. No patient received induction chemotherapy or radiotherapy. Subtotal esophagectomy was performed through a right transthoracic $(n=49)$ or transhiatal approach $(n=42)$. A potentially curative resection was performed, completely resecting all macroscopic tumor, along with the thoracic and abdominal esophagus and the lesser curvature of the stomach, to achieve a minimum 5-cm distal resection margin. ${ }^{34}$ Regional lymph node stations were resected extensively and mapped to document patterns of metastasis. ${ }^{35}$ Reconstruction of the upper gastrointestinal tract was achieved by transposing stomach through the posterior mediastinum with cervical esophagogastrostomy (left side of neck). Long-term postoperative follow-up comprised 3-monthly office visits for the first 3 years, with visits every 6 months thereafter. All reasonable attempts were made to confirm tumor recurrence or metastasis cytologically or histologically with radiologically guided fine-needle aspiration or endoscopic biopsy techniques.

\section{Tumors}

Immediately after esophageal resection, and in collaboration with a consultant pathologist, resected esophageal tissues were examined, and representative sections of the primary tumor (comprising $>80 \%$ malignant cells, with minimal necrosis) and histologically normal esophageal epithelium adjacent to the proximal resection margin were snap frozen in liquid nitrogen and stored in our esophageal tumor bank at $-80^{\circ} \mathrm{C}$. Approval for banking of surgically resected esophageal tissues for molecular studies was obtained from review boards for health science research at the University of Western Ontario (London, Ontario, Canada) and University of Toronto (Ontario, Canada) and from respective departments of pathology. Tissues banked at Heartlands Hospital (Birmingham, UK) were collected according to local protocols. Since 1998 all tissues were banked at Dalhousie University in accordance with the Canadian Tri-Council Policy "Statement on Ethical Conduct for Research Involving Humans."

All remaining esophageal tissues were processed according to standard protocol by collaborating departments of pathology. Representative sections were stained with hematoxylin and eosin and examined by an independent consultant histopathologist. Serial unstained, formalin-fixed, paraffin-embedded tissue sections were used for subsequent immunohistochemical analyses. All tumors were staged according to the International Union Against Cancer (Union Internationale Contre Le Cancer; IUCC) classification on the basis of pTNM subsets. ${ }^{36}$ Strict clinicopathologic criteria (Table 1) were used to define primary esophageal adenocarcinomas (Siewert type I), ${ }^{37}$ thereby excluding adenocarcinomas of the cardia (Siewert type II) or proximal (subcardia) gastric tumors (Siewert type III). Proximal and distal resection margins were considered positive if tumor cells were present in any layer of the esophageal or gastric wall. The radial (lateral) resection margin was considered positive if tumor was present within $1 \mathrm{~mm}$ of the inked surface.

\section{Molecular and Immunohistochemical Analysis of the p53 Gene}

All molecular and immunohistochemical techniques were performed at minimum in duplicate on coded samples by a laboratory technician without knowledge of clinical correlative and outcome data. Methodology has been described in detail previously elsewhere. ${ }^{33}$ Briefly, genomic DNA was extracted from banked esophageal tissues (tumor and matched normal tissue as an internal control), and p53 exons 4 through 10 were amplified by polymerase chain reaction (PCR). Single-strand conformation polymor- 
phism (SSCP) analysis was used to screen for point mutations. Direct DNA sequencing (forward and reverse) was used to confirm the site and nature of each mutation. All samples were reamplified from the original genomic DNA, followed by a second PCR and SSCP with DNA sequencing.

A modified indirect immunoperoxidase technique was used to study the distribution of p53 protein in formalin-fixed, paraffinembedded tissue sections. DO7, a murine monoclonal anti-p53 antibody (recognizing mutant and wild-type p53 protein) was used at 1:50 dilution (Novocastra Laboratories Ltd, Newcastle upon Tyne, UK). Controls were run in parallel with test sections and included known positive and negative tissues (tissue controls), matched histologically normal esophageal mucosa (internal control), and sections stained without the primary antibody (reagent controls). Interpretation and scoring of tissue sections according to intensity and proportion of positively staining cell nuclei have previously been reported in detail. ${ }^{33}$ An individual was considered to have altered p53 if a mutation was confirmed by sequencing or by accumulation of p53 protein (immunopositivity) in tissue sections.

\section{Data Collection and Statistical Analysis}

Clinicopathologic data were prospectively collected and recorded in a research database. Follow-up was complete for all patients until February 2001. Differences in p53 alterations with respect to gender, surgical approach, extent of resection, tumor differentiation, pT stage, $\mathrm{pN}$ stage, UICC stage, and the number of resected metastatic lymph nodes were tested with a $\chi^{2}$ test, with the Fisher exact test used if a cell contained fewer than 5 patients. The prognostic importance of these variables, as well as those of p53 alterations, p53 mutations, and p53 protein expression, for overall and disease-free survival after resection were compared with Kaplan-Meier survival methods and tested with the log-rank test. We applied multivariate Cox proportional hazards regression methods to evaluate the independent importance of p53 for overall and disease-free survival after resection. In this respect, we considered various combinations of variables that potentially confound the associations between p53 alterations and overall and disease-free survival after resection. All analyses were performed with SPSS for Windows 9.0 (SPSS Inc, Chicago, Ill).

\section{Results}

\section{Mortality and Morbidity}

Postoperative (30-day and in-hospital) mortality was $4.4 \%$, resulting from pulmonary embolus $(n=2)$, aspiration $(n=$ $1)$, and myocardial infarction $(\mathrm{n}=1)$. Postoperative course was uncomplicated in $63.7 \%$ of patients $(n=58 / 91)$, with a median stay of 10 days (range 7-27 days). Overall, 33 patients $(36.3 \%)$ had postoperative complications. Postoperative morbidity was associated with prolonged hospitalization that ranged from 9 to 63 days (median 20 days vs 10 days for uncomplicated course, $P \leq .001$ ).

\section{Staging, Clinicopathologic Findings, and Outcome}

Primary tumor histologic type was confirmed to be adenocarcinoma, and all tumors were considered to be of primary esophageal origin after pathologic examination. Thirty- three tumors were well differentiated (G1), 16 were moderately differentiated (G2), and 42 were poorly differentiated (G3). Tumors were staged as I $(\mathrm{n}=9)$, IIA $(\mathrm{n}=25)$, IIB $(\mathrm{n}=7)$, III $(\mathrm{n}=39)$, and IV $(\mathrm{n}=11)$. The stage IV classification was based on the presence of distant (nonregional) lymph node metastases. ${ }^{35,36} \mathrm{~A}$ complete (R0) resection was confirmed histologically in $80.2 \%$ of patients $(\mathrm{n}=$ 73/91). Proximal esophageal and distal gastric resection margins were histologically normal in all cases. Microscopic residual tumor (R1) was documented in $14.3 \%$ of patients $(n=13 / 91)$ at the lateral tumor resection margin. Macroscopic residual tumor (R2) was present in $5.5 \%$ of patients $(n=5 / 91)$, resulting from extracapsular nonregional lymph node metastases. The number or regional lymph nodes identified pathologically ranged from 2 to 26 (mean 10 nodes). Overall 5-year survival was $27.3 \%$, with a median survival of 19 months. Thirty-four patients are currently alive with a median follow-up of 34 months. Recurrent or metastatic disease was documented in $60.4 \%$ of patients $(\mathrm{n}=55 / 91)$ and was predominantly systemic $(89.1 \%, \mathrm{n}=49 / 55)$.

\section{Alterations in p53}

Overall, $57.1 \%$ of patients $(\mathrm{n}=52 / 91)$ in this updated 10 -year series had p53 alterations (mutations and/or protein overexpression). These data are summarized in Table 2. Mutations alone were found in $50.5 \%$ of tumors $(n=46 / 91)$ throughout exons 4 through 10 of the p53 gene. Mutations were missense $(n=32)$ or truncating $(n=14)$, the latter of which comprised nonsense mutations $(n=7)$, base insertions $(\mathrm{n}=5)$, and base deletions $(\mathrm{n}=2)$. G:C to A:T single base substitutions $(n=28)$ were predominant, with 24 of these changes at $\mathrm{CpG}$ dinucleotides. PCR-SSCP analysis of matched normal DNA did not reveal any p53 mutations, and DNA sequencing of tumors with negative results of PCRSSCP confirmed only the wild-type p53 sequence.

The $\mathrm{p} 53$ protein was demonstrated immunohistochemically in $36.2 \%$ of tumors $(n=33 / 91)$. Cell nuclear immunoreactivity was heterogenous throughout tumor tissues, and immunopositivity was scored on the basis of intensity of cell nuclear staining and proportion of immunopositive cells for each tissue section (Table 2), as described previously. ${ }^{33}$ No immunoreactivity was seen in matched histologically normal esophageal mucosa or in any negative control. No p53 mutations (all wild-type p53 confirmed by sequencing) were found in 6 immunopositive tumors (Table 2).

\section{Alterations in p53 and Clinicopathologic Observations} The associations between p53 alterations (mutations and/or protein overexpression) and selected clinicopathologic variables are summarized in Table 3. The p53 alterations were associated with higher stage tumors, lymph node metastasis, and poor tumor differentiation. 
TABLE 2. The p53 alterations (mutations and protein accumulation) in primary esophageal adenocarcinomas

\begin{tabular}{|c|c|c|c|c|c|c|}
\hline & Stage* & SSCPt & Codon & Base change & Amino acid & IHCF \\
\hline \multirow[t]{2}{*}{ Exon 4} & III & + & $91 \S$ & $+\mathrm{G}$ & FS & - \\
\hline & III & + & 132 & $A A G-A G G$ & Lys-Thr & + \\
\hline \multirow[t]{12}{*}{ Exon 5} & IIA & + & 140 & TGC-TAC & Cys-Thr & + \\
\hline & IV & + & $154 \S$ & $+C$ & FS & - \\
\hline & III & + & $158 \S$ & CGC-CAC & Arg-His & + \\
\hline & IIB & + & $158 \S$ & CGC-CAC & Arg-His & - \\
\hline & IV & + & $163 \S$ & TAC-TGC & Tyr-Cys & + \\
\hline & IV & + & $174 \S$ & $-G$ & $\mathrm{FS}$ & - \\
\hline & IV & + & 175 & CGC-CAC & Arg-His & + \\
\hline & III & + & $175 \S$ & CGC-CAC & Arg-His & + \\
\hline & IIA & + & $175 \S$ & CGC-CAC & Arg-His & + \\
\hline & IIA & + & $175 \S$ & CGC-CAC & Arg-His & - \\
\hline & IIA & + & $175 \S$ & CGC-CAC & Arg-His & - \\
\hline & III & + & $179 \S$ & CAT-TAT & His-Tyr & - \\
\hline \multirow{3}{*}{ Exon 6} & III & + & $196 \S$ & CGA-TGA & Arg-Stop & - \\
\hline & IV & + & $196 \S$ & CGA-TGA & Arg-Stop & - \\
\hline & III & + & 213 & CGA-TGA & Arg-Stop & - \\
\hline \multirow[t]{14}{*}{ Exon 7} & III & + & 234 & TAC-TGC & Tyr-Cys & + \\
\hline & IIA & + & $234 \S$ & TAC-AAC & Tyr-Asn & + \\
\hline & III & + & $234 \S$ & TAC-TGC & Tyr-Cys & + \\
\hline & III & + & 236 & $+\mathrm{A}$ & FS & - \\
\hline & I & + & $236 \S$ & $+\mathrm{TA}$ & FS & - \\
\hline & III & + & 237 & ATG-ATA & Met-Ile & - \\
\hline & IV & + & 245 & GGC-AGC & Gly-Ser & - \\
\hline & III & + & 245 & GGC-AGC & Gly-Ser & + \\
\hline & I & + & $245 \S$ & GGC-AGC & Gly-Ser & + \\
\hline & III & + & 246 & ATG-ACG & Met-Thr & + \\
\hline & I & + & 248 & CGG-TGG & Arg-Trp & + \\
\hline & III & + & $248 \S$ & CGG-TGG & Arg-Trp & + \\
\hline & III & + & 249 & AGG-AGT & Arg-Ser & + \\
\hline & III & + & 250 & ССС-СТС & Pro-Leu & + \\
\hline \multirow[t]{11}{*}{ Exon 8} & III & + & $271 \S$ & GAG-TAG & Glu-Stop & + \\
\hline & III & + & 273 & CGT-CAT & Arg-His & + \\
\hline & IIA & + & 273 & CGT-TGT & Arg-Cys & + \\
\hline & III & + & $273 \S$ & CGT-CAT & Arg-His & - \\
\hline & IIA & + & $273 \S$ & CGT-TGT & Arg-Cys & + \\
\hline & III & + & 277 & TGT-TTT & Cys-Phe & + \\
\hline & III & + & 281 & GAC-TAC & Asp-Tyr & + \\
\hline & I & + & 282 & CGG-TGG & Arg-Tpr & - \\
\hline & III & + & $282 \S$ & CGG-TGG & Arg-Trp & - \\
\hline & IIA & + & $306 \S$ & CGA-TGA & Arg-Stop & + \\
\hline & III & + & $306 \S$ & CGA-TGA & Arg-Stop & + \\
\hline \multirow[t]{2}{*}{ Exon 9} & IV & + & $311 \S$ & AAC-CAC & Asp-His & + \\
\hline & III & + & $316 \S$ & $+\mathrm{C}$ & $\mathrm{FS}$ & - \\
\hline \multirow[t]{2}{*}{ Exon 10} & $\| A$ & + & $334 \S$ & $-G$ & FS & + \\
\hline & IV & + & $342 \S$ & CGA-TGA & Arg-Stop & - \\
\hline \multirow[t]{6}{*}{ Protein expression only } & III & - & & & & + \\
\hline & III & - & & & & + \\
\hline & III & - & & & & + \\
\hline & $\| A$ & - & & & & + \\
\hline & III & - & & & & + \\
\hline & III & - & & & & + \\
\hline
\end{tabular}

IHC, Immunohistochemical analysis; Lys, lysine; Thr, threonine; Cys, cysteine; FS, frameshift; Arg, arginine; His, histidine; Tyr, tyrosine; Stop, stop codon; Asn, asparagine; Met, methionine; Ile, isoleucine; Gly, glycine; Ser, serine; Trp, tryptophan; Pro, proline; Leu, leucine; Glu, glutamic acid; Phe, phenylalanine. *UICC classification according to pTNM subsets. ${ }^{36}$

†Plus sign denotes an electrophoretic mobility shift indicative of a point mutation, confirmed by DNA sequencing to define the codon and base change; minus sign denotes no electrophoretic mobility shift (sequence analysis confirmed wild-type p53).

fImmunonegative sections are denoted by minus signs. A composite scoring system ${ }^{33}$ of intensity and proportion of immunopositive tumor cell nuclei was used to determine $\mathrm{p} 53$ protein accumulation, denoted by plus signs.

§Previously reported mutations. ${ }^{33}$ 


\begin{abstract}
Alterations in p53 and Survival
Prognostic variables of overall and disease-free survival are summarized in Table 4. The p53 alterations (mutations and/or protein overexpression) were associated with reduced overall survival (odds ratio 2.26, 95\% confidence interval 1.27-4.00, $P=.004$; Figure 1). Similar observations were made for disease-free survival (odds ratio 2.78; 95\% confidence interval 1.51-5.13, $P=.001$ ). The importance of p53 alterations (mutations and/or protein overexpression) was stronger for disease-free survival than for overall survival. Of all prognostic variables evaluated by multivariate analysis, only tumor stage was statistically significantly associated with survival, with p53 alterations having no statistically significant association when evaluating both overall and disease-free survival.
\end{abstract}

\section{Discussion}

To explore potential clinical applications for the p53 tumor suppressor gene, this prospective study was initiated to characterize the spectrum of p53 alterations (mutations and protein expression) in a well-defined and well-staged series of surgically resected esophageal adenocarcinomas. We studied 91 tumors, documenting p53 alterations (mutations and/or protein overexpression) in $52(57.1 \%)$. In keeping with results obtained from our earlier analysis of the initial 5 years of this 10 -year study, ${ }^{33}$ we have confirmed statistically significant associations between p53 alterations and advanced tumor stage, lymph node metastasis, poor tumor differentiation, and reduced overall and disease-free survival.

In normal cells the p53 gene, localized to chromosome $17 \mathrm{p} 13$, is thought to act as a transcription factor with a wide range of biologic functions, including regulation of cellcycle checkpoints, apoptosis, and maintenance of genomic integrity. ${ }^{11}$ The gene encodes a $53-\mathrm{kd}$ phosphoprotein that does not accumulate to significant levels in normal cells because of rapid turnover (half-life 2-15 minutes). In response to various cellular signals, the p53 protein is stabilized and becomes capable of transactivating several downstream target genes. These complex regulatory molecular mechanisms are thought to prevent DNA replication after genomic damage, either by arresting cells in $\mathrm{G}_{1}$ and allowing more time for DNA repair or by inducing apoptosis (cell death) of cells that contain damaged DNA. ${ }^{11,38-42}$

Point mutations of the p53 tumor suppressor gene are among the most frequent molecular alterations in human malignancies, ${ }^{7,12}$ suggesting that loss of p53 function is critical to tumorigenesis. Missense mutations in conserved regions of the DNA-binding domain of p53 (exons 5-8) result in the loss of ability of p53 to bind DNA in a sequence-specific manner, preventing the gene from transactivating its physiologic molecular targets. ${ }^{43}$ Alternative molecular mechanisms of inactivation have also been described, including accelerated protein degradation through
TABLE 3. Proportion of p53 alterations for selected clinicopathologic parameters

\begin{tabular}{|c|c|c|c|}
\hline & \multicolumn{2}{|c|}{$\begin{array}{c}\text { p53 } \\
\text { Alterations }\end{array}$} & \multirow[b]{2}{*}{$P$ value } \\
\hline & No. & $\%$ & \\
\hline Gender & & & .542 \\
\hline Male & $42 / 73$ & 58 & \\
\hline Female & $10 / 18$ & 56 & \\
\hline Surgical approach & & & .262 \\
\hline Right thoracotomy & $30 / 49$ & 61 & \\
\hline Transhiatal & $22 / 42$ & 52 & \\
\hline Extent of resection & & & .010 \\
\hline Complete (RO) & $37 / 73$ & 51 & \\
\hline Incomplete (R1, R2) & $15 / 18$ & 83 & \\
\hline Tumor differentiation (grade) & & & .002 \\
\hline Well differentiated (G1) & $11 / 33$ & 33 & \\
\hline Moderately differentiated (G2) & $10 / 16$ & 63 & \\
\hline Poorly differentiated (G3) & $31 / 42$ & 74 & \\
\hline T stage & & & .079 \\
\hline pT1 & $4 / 9$ & 44 & \\
\hline pT2 & $7 / 19$ & 37 & \\
\hline pT3 & $35 / 56$ & 63 & \\
\hline pT4 & $6 / 7$ & 86 & \\
\hline $\mathrm{N}$ stage & & & .014 \\
\hline pNO & $15 / 36$ & 42 & \\
\hline pN1 & $37 / 55$ & 67 & \\
\hline UICC stage & & & .009 \\
\hline I & $4 / 9$ & 44 & \\
\hline$\| A$ & $9 / 25$ & 36 & \\
\hline IIB & $2 / 7$ & 29 & \\
\hline III & $28 / 39$ & 72 & \\
\hline IV & $9 / 11$ & 82 & \\
\hline No. of metastatic nodes resected & & & .044 \\
\hline 0 & $15 / 36$ & 42 & \\
\hline $1-3$ & $17 / 27$ & 63 & \\
\hline$>3$ & $20 / 28$ & 71 & \\
\hline
\end{tabular}

interaction with cellular (mdm2) or viral (HPV E6) oncoproteins and cytoplasmic retention and accumulation of wildtype p53. ${ }^{44,45}$ However, it is not known with certainty which of these p53 activities is the most critical for tumorigenesis, and p53 activity may further be influenced by cell type and epigenetic modifiers. Regardless of the molecular mechanism, the resulting loss of p53 function is thought to enhance genomic instability in cancer cells, predisposing toward accumulation of multiple molecular genetic alterations.

In addition to providing further insight into fundamental biologic mechanisms associated with tumor development, there has been considerable interest in potential clinical applications of p53 for early diagnosis, staging, prognosis, as a predictor of cytotoxic drug sensitivity or resistance, and as a molecular target for gene therapies. ${ }^{46,47}$ Such approaches that use p53 and other molecular biomarkers are particularly important for esophageal cancer, because longterm prognosis for this disease is poor. 
TABLE 4. Univariate analysis of selected prognostic factors for survival after surgical resection of primary esophageal adenocarcinomas

\begin{tabular}{|c|c|c|c|c|}
\hline & $\begin{array}{c}\text { 5-y survival } \\
(\%)\end{array}$ & $\begin{array}{l}\text { Odds } \\
\text { ratio }\end{array}$ & $\begin{array}{l}95 \% \text { Confidence } \\
\text { interval }\end{array}$ & $P$ value \\
\hline \multicolumn{5}{|l|}{ Overall survival } \\
\hline Gender & & & & .07 \\
\hline Male & 22 & & & \\
\hline Female & 47 & 0.52 & $0.25-1.06$ & \\
\hline Surgical approach & & & & .61 \\
\hline Right thoracotomy & 27 & & & \\
\hline Transhiatal & 29. & 0.87 & $0.52-1.50$ & \\
\hline Extent of resection & & & & .0001 \\
\hline Complete (R0) & 33 & & & \\
\hline Incomplete (R1, R2) & 0 & 6.03 & $3.02-12.06$ & \\
\hline Tumor differentiation (grade) & & & & .0001 \\
\hline Well differentiated (G1) & 56 & & & \\
\hline Moderately differentiated (G2) & 18 & 2.70 & $1.12-6.49$ & \\
\hline Poorly differentiated (G3) & 7 & 5.62 & $2.86-11.03$ & \\
\hline T stage & & & & .0006 \\
\hline pT1 & 100 & & & \\
\hline pT2 & 43 & 4.7 & $0.60-38.90$ & \\
\hline рT3 & 17 & 9.8 & $1.35-71.90$ & \\
\hline pT4 & 0 & 32.6 & $3.90-281.80$ & \\
\hline $\mathrm{N}$ stage & & & & .0001 \\
\hline pNO & 60 & & & \\
\hline $\mathrm{pN1}$ & 5 & 8.9 & $4.2-18.80$ & \\
\hline International Union Against Cancer stage & & & & .0001 \\
\hline I & 100 & & & \\
\hline ॥A & 55 & 2.7 & $0.34-21.70$ & \\
\hline IIB & 14 & 17.0 & $1.91-151.31$ & \\
\hline III & 6 & 22.4 & $2.86-175.89$ & \\
\hline IV & 0 & 32.6 & $3.90-281.80$ & \\
\hline No. of metastatic lymph nodes resected & & & & .0001 \\
\hline 0 & 60 & & & \\
\hline $1-3$ & 7 & 6.4 & $2.87-14.29$ & \\
\hline$>3$ & 4 & 18.9 & $8.03-44.2$ & \\
\hline p53 Alterations & & & & .004 \\
\hline Mutation or protein expression & 15 & & & \\
\hline Wild-type & 46 & 2.26 & $1.27-4.00$ & \\
\hline p53 Mutations & & & & .080 \\
\hline Mutation present & 17 & & & \\
\hline Wild-type & 40 & 1.59 & $0.93-2.72$ & \\
\hline p53 Protein expression & & & & .052 \\
\hline Immunopositive & 20 & & & \\
\hline Immunonegative & 32 & 1.69 & $1.00-2.86$ & \\
\hline Disease-free survival & & & & \\
\hline Gender & & & & .74 \\
\hline Male & 24 & & & \\
\hline Female & 41 & 0.64 & $0.32-1.28$ & \\
\hline Surgical approach & & & & .20 \\
\hline Right thoracotomy & 27 & & & \\
\hline Transhiatal & 30 & 0.71 & $0.41-1.21$ & \\
\hline Extent of resection & & & & .0001 \\
\hline Complete (R0) & 35 & & & \\
\hline Incomplete (R1, R2) & 0 & 7.32 & $3.80-14.21$ & \\
\hline Tumor differentiation (grade) & & & & .0001 \\
\hline Well differentiated (G1) & 70 & & & \\
\hline Moderately differentiated (G2) & 14 & 5.37 & $2.12-13.62$ & \\
\hline Poorly differentiated (G3) & 0 & 9.96 & $4.49-22.09$ & \\
\hline T stage & & & & .002 \\
\hline pT1 & 50 & & & \\
\hline pT2 & 36 & 5.15 & $0.66-39.88$ & \\
\hline
\end{tabular}


TABLE 4. Continued

\begin{tabular}{|c|c|c|c|c|}
\hline & $\begin{array}{c}\text { 5-y survival } \\
(\%)\end{array}$ & $\begin{array}{l}\text { Odds } \\
\text { ratio }\end{array}$ & $\begin{array}{c}95 \% \text { Confidence } \\
\text { interval }\end{array}$ & $P$ value \\
\hline pT3 & 24 & 9.51 & $1.30-69.46$ & \\
\hline pT4 & 0 & 42.30 & $4.92-363.44$ & \\
\hline $\mathrm{N}$ stage & & & & .0001 \\
\hline pNO & 59 & & & \\
\hline pN1 & 6 & 8.33 & $4.02-17.26$ & \\
\hline UICC stage & & & & .0001 \\
\hline I & 50 & & & \\
\hline IIA & 64 & 2.27 & $0.28-18.14$ & \\
\hline IIB & 0 & 19.12 & $2.27-161.19$ & \\
\hline III & 9 & 19.79 & $2.62-147.37$ & \\
\hline IV & 0 & 101.48 & $4.92-363.44$ & \\
\hline No. of metastatic lymph nodes resected & & & & .0001 \\
\hline 0 & 59 & & & \\
\hline $1-3$ & 13 & 5.38 & $2.41-12.02$ & \\
\hline$>3$ & 0 & 22.84 & $9.81-53.15$ & \\
\hline p53 Alterations & & & & .001 \\
\hline Mutation and/or protein overexpression & 9 & & & \\
\hline Wild-type & 54 & 2.78 & $1.51-5.13$ & \\
\hline p53 Mutations & & & & .010 \\
\hline Mutation present & 9 & & & \\
\hline Wild-type & 48 & 2.07 & $1.18-3.62$ & \\
\hline p53 Protein expression & & & & .020 \\
\hline Immunopositive & 0 & & & \\
\hline Immunonegative & 36 & 1.90 & $1.11-3.23$ & \\
\hline
\end{tabular}

To date few studies have critically evaluated the prognostic significance of p53 alterations in esophageal adenocarcinoma. In a combined series of adenocarcinomas $(\mathrm{n}=$ $24)$ and squamous cell carcinomas $(n=63)$ of the esophagus, p53 protein accumulation (shown immunohistochemically) was reported in 19 (79\%) adenocarcinomas but was not associated with outcome after surgical resection. ${ }^{24}$ One further combined series of esophageal tumors $(n=21$ adenocarcinomas, $\mathrm{n}=46$ squamous cell carcinomas) also reported that p53 mutations $(40.5 \%)$ and p53 protein accumulation $(59.5 \%)$ were not related to postoperative survival. ${ }^{48}$ By contrast, improved survival of patients with adenocarcinomas with p53 protein overexpression (50\% of tumors) was reported by Sauter and colleagues 25 in a phase II study of 24 patients treated with chemotherapy (5-fluorouracil and mitomycin C), radiotherapy (60 Gy), and surgical resection. In addition to our initial report of 48 patients with esophageal adenocarcinomas who underwent surgical resection alone, ${ }^{33}$ two studies have now demonstrated poor prognosis for patients with esophageal adenocarcinomas found to have p53 mutations. Ribeiro and coworkers $^{29}$ evaluated 42 patients with esophageal adenocarcinoma treated by chemotherapy (5-fluorouracil, cisplatin, and $\alpha$-interferon), radiation therapy (45 Gy) and surgery, correlating p53 mutations $(40.5 \%)$ and p53 protein expression $(59.5 \%)$ with significantly reduced overall and disease-free survival. Comparable results were also recently reported by Schneider and colleagues, ${ }^{31}$ who found that p53 mutations $(50.8 \%)$ were associated with significantly reduced survival in a series of 59 patients who underwent potentially curative surgical resection of esophageal adenocarcinoma.

Several factors may account for the conflicting results reported in the preceding studies, and the limitations of evaluating molecular biomarkers in clinical correlative studies are well known. ${ }^{49-51}$ Such limitations include use of variable treatment strategies (eg, use of induction chemotherapy or radiotherapy, different operative procedures), relatively low patient numbers to achieve sufficient statistical power, lack of a strict definition for primary esophageal adenocarcinomas, incomplete pathologic staging, differing techniques for evaluating p53 (mutation analysis vs immunohistochemical analysis), and technical issues related to tumor heterogeneity.

Although we have attempted to overcome such limitations where possible, it is important to note that these data reflect a selected series of patients referred for potentially curative esophageal resection at tertiary university centers and may therefore not necessarily be representative of esophageal adenocarcinoma in the general population. However, the surgical results, prognostic factors (eg, stage), and survival rates in this study are comparable with those in other recent series reporting surgical outcomes with esophageal cancer. ${ }^{52-56}$ In contrast to previously reported studies 


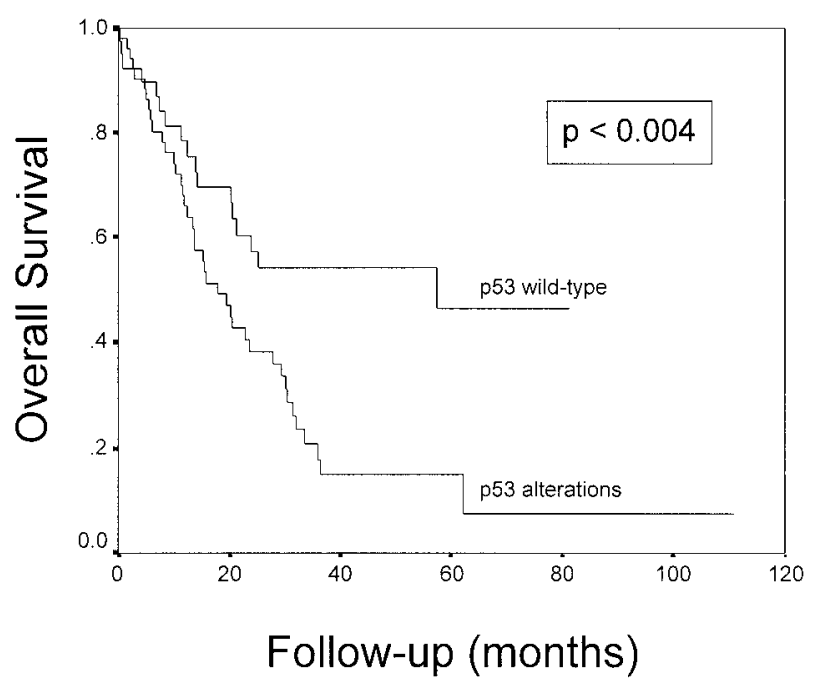

Figure 1. Kaplan-Meier survival curves for patients after surgical resection of primary esophageal adenocarcinoma categorized by p53 status. Statistically significantly improved overall survival was seen for patients $(\mathrm{n}=39$ ) with tumors found to have wildtype p53 relative to patients $(n=52)$ with tumors showing p53 alterations (mutations and/or protein overexpression).

evaluating the prognostic significance of p53 in esophageal adenocarcinoma, ${ }^{25,29}$ no patient received induction therapy (as is current clinical practice in our center), and all patients were treated by a single surgeon with consistent operative technique. Of particular importance was our use of strict clinicopathologic criteria ${ }^{13,33}$ to define adenocarcinomas of primary esophageal origin (Siewert type I). ${ }^{37}$ The recent demonstration of molecular differences between adenocarcinomas of the esophagus (Siewert type I) and cardia (Siewert type II), suggesting that these represent different pathologic entities, may therefore influence future treatment strategies. ${ }^{57}$ During the past decade, we have used a different operative approach to resect cardia adenocarcinomas (Siewert type II): a left thoracoabdominal extended gastrectomy, incorporating the distal thoracic esophagus to the level of the inferior pulmonary vein, with esophagojejunal Roux-en-Y reconstruction.

Techniques to evaluate p53 may further account for discordant results between previously reported prognostic studies. The advantages and limitations of immunohistochemical analysis of p53 protein versus molecular analysis of p53 mutations have previously been addressed in detail. ${ }^{58,59}$ In this study, either approach was found to have a statistical association with survival, but the combination of p53 alterations (mutations and/or protein overexpression) was most significant.

Molecular analysis of the p53 gene has provided valuable fundamental information regarding the biology of esophageal adenocarcinoma. ${ }^{60} \mathrm{~A}$ high proportion of $\mathrm{p} 52$ mutations (30.4\%) found in this study were truncating mutations that resulted in a null-protein phenotype and are therefore undetectable by immunohistochemical means. In contrast, some tumors were immunopositive, with no mutations in p53. Rare instances of mutations outside p53 exons 4 through 10 have been described, ${ }^{61}$ but there is also evidence that mechanisms other than point mutation may result in p53 protein accumulation and inactivation (eg, cytoplasmic p53 protein accumulation in a subset of breast cancer62 and in neuroblastoma ${ }^{45}$ ).

In agreement with these considerations, our results indicate that the combination of mutation analysis and immunohistochemical analysis discriminates a group of tumors with more aggressive clinical and biologic properties. This biologic effect is reflected to some extent by an increasing statistically significant relationship between p53 status (mutations, protein overexpression, or both) and reduced disease-free survival relative to overall survival. Furthermore, esophageal adenocarcinomas with p53 alterations tend to be more poorly differentiated than tumors with wild-type p53, suggesting that the p53 tumor suppressor gene contributes to maintain cancer cells in a low-differentiation, high-proliferation state. Similar associations between p53 and poor tumor differentiation have previously been reported for other upper aerodigestive tract tumors, including non-small cell lung cancer, ${ }^{63}$ and for head and neck cancers. ${ }^{64}$

Biologically, one of the most interesting lessons derived from analysis of p53 mutations in esophageal cancer relates to patterns of mutations. ${ }^{60,61}$ Patterns of p53 mutations in squamous cell carcinoma of the esophagus are predominantly transitions or transversions occurring at A:T base pairs (suggesting a relationship to metabolites of ethanol, a well-defined risk factor for squamous cell carcinomas), or G to $\mathrm{T}$ transversions (a characteristic mutation attributed to benzo[a]pyrine, suggesting an association with tobacco). ${ }^{61}$ For esophageal adenocarcinomas, however, predominant mutations are $\mathrm{G}: \mathrm{C}$ to $\mathrm{A}: \mathrm{T}$ transitions at $\mathrm{CpG}$ dinucleotides (52.2\% in this study). A review of all published human p53 mutations (see IARC p53 mutation database at http:// www.iarc.fr/p53/index.html) indicates that esophageal adenocarcinomas are the cancer type with the highest proportion of such mutations. There is now solid molecular evidence that these mutations primarily arise through endogenous mechanisms, involving the spontaneous deamination into thymine of the $5^{\prime}$ methylated cytosine that frequently occurs at $\mathrm{CpG}$ dinucleotides. ${ }^{61}$ This mechanism is enhanced by exposure to oxyradicals and nitroradicals. In colon cancer, Ambs and associates ${ }^{65}$ demonstrated a direct correlation between the levels of expression of nitric oxide synthase 2 and the rate of formation of G:C to A:T transition at $\mathrm{CpG}$ dinucleotides, incriminating overproduction of nitric oxide as a major causative factor. Our data support the hypothesis that chronic stress, in particular that related to 
gastroesophageal reflux, may result in local overproduction of nitric oxide in normal and metaplastic esophageal mucosa, thus enhancing the rate of formation of spontaneous p53 mutations. This observation may provide a basis for chemopreventive approaches aimed at reducing the levels of nitric oxide production in the lower esophagus of individuals at increased risk for esophageal adenocarcinoma.

It seems likely that further progress with esophageal adenocarcinoma will only be made with a clearer understanding of its tumor biology. Recent advances in molecular technology will also permit the identification of multiple biomarkers and global gene expression profiles to be studied in esophageal tissues. ${ }^{66}$ Barrett esophagus is an excellent model to study early molecular alterations associated with tumorigenesis. Several early molecular alterations in Barrett epithelium have now been described ${ }^{8,67}$ and will probably form the basis of further strategies for early detection, prevention and therapy. ${ }^{68}$

For expert technical advice and assistance regarding molecular analysis of the p53 gene, we thank Giselle Martel-Planche (IARC, Lyon, France). We thank Sasha Eskandarian (Lunenfeld Research Institute, Toronto, Ontario, Canada) for performing the initial molecular and immunohistochemical studies. For follow-up, we thank the following clinical trials nurses and administrative assistants: Bev Neskas, Sue Troyan, RN, and Natalie Zankowicz, RN (London, Ontario, Canada); Susan Rosgen, RN, and Frances Hui (Toronto, Ontario, Canada); and Dianne Russell (Halifax, Nova Scotia, Canada). We also thank participating patients, their families and personal physicians, and the Cancer Intelligence Unit (West Midlands, Birmingham, UK). The following consultant pathologists were invaluable for expert clinical histopathologic review at each respective center: Dr M. Troster (London, Ontario, Canada); Dr M. Redston (Toronto, Ontario, Canada); Dr J. Newman and Professor J. Crocker (Birmingham, UK); and Dr D. Malatjalian (Halifax NS). We thank John Fris for data management.

\section{References}

1. Devesa SS, Blot WJ, Fraumeni JF. Changing patterns in the incidence of esophageal and gastric carcinoma in the United States. Cancer. 1998;83:2049-53.

2. Powell J, McConkey CC. The rising trend in oesophageal adenocarcinoma and gastric cardia. Eur J Cancer Prev. 1992;1:265-9.

3. Zhang ZF, Kurtz RC, Sun M, Karpeh M, Yu GP, Gargon N, et al. Adenocarcinomas of the esophagus and gastric cardia: Medical conditions, tobacco, alcohol, and socioeconomic factors. Cancer Epidemiol Biomarkers Prev. 1996;5:761-8.

4. Gammon MD, Schoenberg JB, Ahsan H, Risch HA, Vaughan TL, Chow WH, et al. Tobacco, alcohol, and socioeconomic status and adenocarcinomas of the esophagus and gastric cardia. J Natl Cancer Inst. 1997;89:1277-84.

5. Lagergren J, Bergstrom R, Lindgren A, Nyren O. Symptomatic gastroesophageal reflux as a risk factor for esophageal adenocarcinoma. N Engl J Med. 1999;340:825-31.

6. Mayne ST, Risch HA, Dubrow R, Chow WH, Gammon MD, Vaughan TL, et al. Nutrient intake and risk of subtypes of esophageal and gastric cancer. Cancer Epidemiol Biomarkers Prev. 2001;10:1055-62.

7. Montesano R, Hollstein M, Hainaut P. Genetic alterations in esophageal cancer and their relevance to etiology and pathogenesis: a review. Int J Cancer (Pred Oncol). 1996;69:225-35.
8. Jankowski JA, Wright NA, Meltzer SJ, Triadafilopoulos G, Geboes K, Casson AG, et al. Molecular evolution of the metaplasia-dysplasiaadenocarcinoma sequence in the esophagus. Am J Pathol. 1999;154: 965-73.

9. Wijnhoven BP, Tilanus HW, Dinjens WN. Molecular biology of Barrett's adenocarcinoma. Ann Surg. 2001;233:322-37.

10. Chen X, Yang CS. Esophageal adenocarcinoma: a review and perspectives on the mechanism of carcinogenesis and chemoprevention. Carcinogenesis. 2001;22:1119-29.

11. Prives C, Hall PA. The p53 pathway. J Pathol. 1999;187:112-26.

12. Hainaut $P$, Hernandez $T$, Robinson A, Rodriguez-Tome P, Flores T, Hollstein M, et al. IARC database of p53 gene mutations in human tumors and cell lines: updated compilation, revised formats and new visualization tools. Nucleic Acids Res. 1998; 26:205-13.

13. Casson AG, Mukhopadhyay T, Cleary KR, Ro JY, Levin B, Roth JA. Oncogene activation in esophageal cancer. J Thorac Cardiovasc Surg. 1991;102:707-10.

14. Casson AG, Mukhopadhyay T, Cleary KR, Ro JY, Levin B, Roth JA. p53 gene mutations in Barrett's epithelium and esophageal cancer. Cancer Res. 1991;51:4495-9.

15. Bennett WP, Hollstein MC, Metcalf RA, Welsh JA, He A, Zhu S, et al p53 mutation and protein accumulation during multistage human esophageal carcinogenesis. Cancer Res. 1992;52:6092-7.

16. Neshat K, Sanchez CA, Galipeau PC, Blount PL, Levine DS, Joslyn $\mathrm{G}$, et al. p53 mutations in Barrett's adenocarcinoma and high-grade dysplasia. Gastroenterology. 1994;106:1589-95.

17. Hamelin R, Flejou JF, Muzeau F, Potet F, Laurent-Puig P, Fekete F, et al. TP53 gene mutations and p53 protein immunoreactivity in malignant and premalignant Barrett's esophagus. Gastroenterology. 1994;107:102-18.

18. Gleeson CM, Sloan JM, McGuigan JA, Ritchie AJ, Russell SE. Base transitions at $\mathrm{CpG}$ dinucleotides in the p53 gene are common in esophageal adenocarcinoma. Cancer Res. 1995;55:3406-11.

19. Moskaluk CA, Heitmiller R, Zahurak M, Schwab D, Sidransky D, Hamilton SR. p53 and p21 WAF1/CIP1/SDI1 gene products in Barrett esophagus and adenocarcinoma of the esophagus and esophagogastric junction. Hum Pathol. 1996;27:1211-20.

20. Schneider PM, Casson AG, Levin B, Garewal HS, Hoelscher AH, Becker K, et al. Mutations of p53 in Barrett's esophagus and Barrett's cancer: a prospective study of 98 cases. J Thorac Cardiovasc Surg. 1996;111:323-33.

21. Sarbia M, Porschen R, Borchard F, Horstmann O, Willers R, Gabbert HE. $\mathrm{p} 53$ protein expression and prognosis in squamous cell carcinoma of the esophagus. Cancer. 1994;74:2218-23.

22. Jones DR, Davidson AG, Summers CL, Murray GF, Quinlan DC. Potential application of p53 as an intermediate biomarker in Barrett's esophagus. Ann Thorac Surg. 1994;57:598-603.

23. Rice TW, Goldblum JR, Falk GW, Tubbs RR, Kirby TJ, Casey G. p53 immunoreactivity in Barrett's metaplasia, dysplasia, and carcinoma. J Thorac Cardiovasc Surg. 1994;108:1132-7.

24. Vijeyasingam R, Darnton SJ, Jenner K, Allen CA, Billingham C, Matthews HR. Expression of p53 protein in oesophageal carcinoma: clinicopathological correlation and prognostic significance. Br J Surg. 1994;81:1623-6.

25. Sauter ER, Keller SM, Erner SM. p53 correlates with improved survival in patients with esophageal adenocarcinoma. J Surg Oncol. 1995;58:269-73.

26. Casson AG, Kerkvliet N, O’Malley F. Prognostic value of p53 protein in esophageal adenocarcinoma. J Surg Oncol. 1995;60:5-11.

27. Monges GM, Seitz JF, Giovannini MF, Gouvernet JM, Torrente MA, Hassoun JA. Prognostic value of 553 protein expression in squamous cell carcinoma of the esophagus. Cancer Detect Prev. 1996;20:63-7.

28. Uchino S, Saito T, Inomata M, Osawa N, Chikuba K, Etoh K, et al. Prognostic significance of the p53 mutation in esophageal cancer. Jpn J Clin Oncol. 1996;26:287-92.

29. Ribeiro U, Finkelstein SD, Safatle-Riberio AV, Landreneau RJ, Clarke MR, Bakker A, et al. p53 sequence analysis predicts treatment response and outcome of patients with esophageal carcinoma. Cancer. 1998;83:7-18.

30. Krasna MJ, Mao YS, Sonett JR, Tamura G, Jones R, Suntharalingam $\mathrm{M}$, et al. p53 gene protein overexpression predicts results of trimo- 
dality therapy in esophageal cancer patients. Ann Thorac Surg. 1999; 68:2021-5.

31. Schneider PM, Stoeltzing O, Roth JA, Hoelscher AH, Wegerer S, Mizumoto S, et al. p53 mutational status improves estimation of prognosis in patients with curatively resected adenocarcinoma in Barrett's esophagus. Clin Cancer Res. 2000;6:3153-8.

32. Aloia TA, Harpole DH, Reed CE, Allegra C, Moore MB, Herndon JE, et al. Tumor marker expression is predictive of survival in patients with esophageal cancer. Ann Thorac Surg. 2001;72:859-66.

33. Casson AG, Tammemagi M, Eskandarian S, Redston M, McLaughlin J, Ozcelik H. p53 alterations in oesophageal cancer: association with clinicopathological features, risk factors, and survival. J Clin Pathol: Mol Pathol 1998;51:71-9.

34. Casson AG, Darnton SJ, Subramanian S, Hiller L. What is the optimum distal resection margin for esophageal carcinoma? Ann Thorac Surg. 2000;69:205-9.

35. Casson AG, Rusch VW, Ginsberg RJ, Zankowicz N, Finley RJ. Lymph node mapping of esophageal cancer. Ann Thorac Surg. 1994; 58:1569-70.

36. Sobin LH, Wittekind C, editors. TNM classification of malignant tumours. 5th ed. New York: Wiley-Liss; 1997. p. 54-7.

37. Siewert JR, Stein HJ. Classification of adenocarcinoma of the oesophagastric junction. Br J Surg. 1998;85:1457-9.

38. Kastan MB, Onyekwere O, Sidransky D, Vogelstein B, Craig RW. Participation of $\mathrm{p} 53$ protein in the cellular response to DNA damage. Cancer Res. 1991;51:6304-11.

39. Zahn Q, Carrier F, Fornace AJ. Induction of cellular p53 activity by DNA-damaging agents and growth arrest. Mol Cell Biol. 1993;13: 4242-50.

40. Tishler RB, Calderwood SK, Coleman CN, Price BD. Increases in sequence specific DNA binding by $\mathrm{p} 53$ following heat treatment with chemotherapeutic and DNA damaging agents. Cancer Res. 1993;53: 2212-6.

41. Levine AJ. p53, the cellular gatekeeper for growth and division. Cell. 1997;88:323-31.

42. Agarwal ML, Taylor WR, Chernov MV, Chernova OB, Stark GR. The p53 network. J Biol Chem. 1998;273:1-4.

43. Martin AC, Facchiano AM, Cuff AL, Hernandez-Boussard T, Oliver $\mathrm{M}$, Hainaut $\mathrm{P}$, et al. Integrating mutation data and structural analysis of the TP tumor-suppressor protein. Hum Mutat. 2002;19:149-64.

44. Riou G, Le MG, Travagli JP, Levine AJ, Moll UM. Poor prognosis of p53 gene mutation and nuclear overexpression of p53 protein in inflammatory breast carcinoma. J Natl Cancer Inst. 1993;85:1765-7.

45. Moll UM, La Quaglia M, Benard J, Riou G. Wild-type p53 protein undergoes cytoplasmic sequestration in undifferentiated neuroblastomas but not in differentiated tumors. Proc Natl Acad Sci U S A. 1995;92:4407-11.

46. Harris CC. Structure and function of the p53 tumor suppressor gene: clues for rational cancer therapeutic strategies. J Natl Cancer Inst. 1996;88:1442-55.

47. Wallace-Brodeur RR, Lowe SW. Clinical implications of p53 mutations. Cell Mol Life Sci. 1999;54:64-75.

48. Coggi G, Bosari S, Roncalli M, Graziani D, Bossi P, Viale G, et al. p53 protein accumulation and p53 mutation in esophageal carcinoma: a molecular and immunohistochemical study with clinicopathologic correlation. Cancer. 1997;79:425-32.

49. Hayes DF, Bast RC, Desch CE, Fritsche H, Kemeny NE, Jessup JM, et al. Tumor marker utility grading system: a framework to evaluate clinical utility of tumor markers. J Natl Cancer Inst. 1996;88:1456-66.

50. Fleming TR, DeMets DL. Surrogate end points in clinical trials: are we being misled? Ann Intern Med. 1996;125:605-13.

51. Pepe MS, Etzioni R, Feng Z, Potter JD, Thompson ML, Thornquist M, et al. Phases of biomarker development for early detection of cancer. J Natl Cancer Inst. 2001;93:1054-61.

52. Steup WH, De Leyn P, Deneffe G, Van Raemdonck D, Coosemans W, Lerut T. Tumors of the esophagogastric junction: long-term survival in relation to the pattern of lymph node metastasis and a critical analysis of the accuracy or inaccuracy of pTNM classification. $J$ Thorac Cardiovasc Surg. 1996;111:85-95.

53. Ellis FH, Heatley GJ, Krasna MJ, Williamson WA, Balogh K. Esophagogastrectomy for carcinoma of the esophagus and cardia: a compar- ison of findings and results after standard resection in three consecutive eight-year intervals with improved staging criteria. $J$ Thorac Cardiovasc Surg. 1997;113:836-48.

54. Visbal AL, Allen MS, Miller DL, Deschamps C, Trastek VF, Pairolero PC. Ivor Lewis esophagogastrectomy for esophageal cancer. Ann Thorac Surg. 2001;71:1803-8.

55. Swanson SJ, Batirel HF, Bueno R, Jaklitsch MT, Lukanich JM, Allred E, et al. Transthoracic esophagectomy with radical mediastinal and abdominal lymph node dissection and cervical esophagogastrostomy for esophageal carcinoma. Ann Thorac Surg. 2001;72:1918-25.

56. van Sandick JW, van Lanschot JB, ten Kate FJ, Tijssen JG, Obertop H. Indicators of prognosis after transhiatal esophageal resection without thoracotomy for cancer. J Am Coll Surg. 2002;194:28-36.

57. Taniere P, Martel-Planche G, Maurici D, Lombard-Bohas C, Scoazec JY, Montesano R, et al. Molecular and clinical differences between adenocarcinomas of the esophagus and of the gastric cardia. Am J Pathol. 2001;158:33-40.

58. Wynford-Thomas D. p53 in tumor pathology: can we trust immunocytochemistry? J Pathol. 1992;166:329-30.

59. Elledge RM. Assessing p53 status in breast cancer prognosis: where should you put the thermometer if you think your p53 is sick? J Natl Cancer Inst. 1996;88:141-3.

60. Hainaut P, Vahakangas K. p53 as a sensor of carcinogenic exposures: mechanisms of p53 protein induction and lessons from p53 gene mutations. Pathol Biol. 1997;45:833-44.

61. Hainaut P, Hollstein M. p53 and human cancer: the first ten thousand mutations. Adv Cancer Res. 2000;77:81-137.

62. Moll UM, Riou G, Levine AJ. Two distinct mechanisms alter p53 in breast cancer: mutation and nuclear exclusion. Proc Natl Acad Sci U S A. 1992;89:7262-6.

63. Shin DM, Lee JS, Lippman SM, Lee JJ, Tu ZN, Choi G, et al. p53 expression: predicting recurrence and second primary tumors in head and neck squamous cell carcinoma. J Natl Cancer Inst. 1996;88:51929.

64. Dalquen P, Sauter G, Torhorst J, Schultheiss E, Jordan P, Lehmann S, et al. Nuclear p53 overexpression is an independent prognostic parameter in node-negative non-small cell lung carcinoma. J Pathol. 1996;178:53-8.

65. Ambs S, Bennett WP, Merriam WG, Ogunfusika MO, Oser SM, Harrington AM, et al. Relationship between p53 mutations and inducible nitric oxide synthase expression in human colorectal cancer. J Natl Cancer Inst. 1999;91:86-8.

66. Selaru FM, Zou T, Xu Y, Shustova V, Yin J, Mori Y, et al. Global gene expression profiling in Barrett's esophagus and esophageal cancer: a comparative analysis using cDNA microarrays. Oncogene. 2002;21:475-8.

67. Casson AG. Role of molecular biology in the follow-up of patients who have Barrett's esophagus. Chest Surg Clin North Am. 2002;12: 93-111.

68. O'Shaughnessy JA, Keloff GJ, Gordon GB, Dannenberg AJ, Hong WK, Fabian CJ, et al. Treatment and prevention of intraepithelial neoplasia: an important target for accelerated new agent development. Clin Cancer Res. 2002;8:314-46

\section{Discussion}

Dr Stephen G. Swisher (Houston, Tex). I enjoyed your presentation. You know that p53 can be knocked out not only by mutations and changes in protein, but by defects in downstream genes that p53 turns on. Have you looked at any other of these genes or are you planning to?

Dr Casson. Through the years we have looked at selected genes. The p53 gene is the one that we have had the most experience with in this sort of translational study. You are quite right, the complexities of p53 are ever increasing, but we have not looked at other pathways yet. We are more interested now in doing that in the early stages, and I think that will be more profitable in terms of, for example, chemopreventive strategies. 
Dr Steven J. Mentzer (Boston, Mass). You mentioned that down the road you want to look at Barrett esophagus and look at early-stage lesions, I presume. Do you see any heterogeneity in terms of p53 expression within the tumors and perhaps adjacent mucosa?

Dr Casson. Yes, and, in fact that was our original report in Cancer Research. The mutations that we found in the tumor were really quite discordant with the associated "premalignant tissues" nearby. Again, it is heartening to see that others have reported the same, and in head and neck cancer and lung cancer as well. Heterogeneity is key to these sorts of studies. Certainly for Barrett esophagus we are going to overcome this issue by laser capture microdissection.

Dr Thomas K. Waddell (Toronto, Ontario, Canada). I compliment you on being careful to separate your clinical material into clinical categories, specifically type I and type II cardia or gastroesophageal junction tumors. Do you actually have any molecular data on the type II tumors? Are they a distinct cancer from a p53 point of view, or just from the perspective of clinical classification?

Dr Casson. The only work I am aware of was actually recently published by Phillippe Taniere at the Cancer Agency, and he has looked at p53, mdm-2, and a couple of other markers as yet unpublished. He wrote this up in the American Journal of Pathology, I think last year, and showed quite different profiles of mutation in tumors that were categorized in that manner. I understand that group has a collaborative project with Siewert's group, which again has a good series of well-stratified tumors. We have not yet done that. In part, the number of cardia cancers I have operated on during the last decade is much smaller. I have only 18 in my personal series, as opposed to the 91 esophageal tumors. 